STUDIA ROSSICA POSNANIENSIA, vol. XXXIX: 2014, pp. 143-149. ISBN 978-83-232-2747-2. ISSN 0081-6884.

Adam Mickiewicz University Press, Poznań

\title{
TYPOLOGIA HOMONIMII JEZZYKOWEJ Z PUNKTU WIDZENIA PRAGMATYKI
}

\author{
TYPOLOGY OF LINGUISTIC HOMONYMY FROM A PRAGMATIC \\ POINT OF VIEW
}

MARTYNA KRÓL

\begin{abstract}
The paper proposes a new approach to the phenomenon of homonymy. The typology of homonymy was prepared from a pragmatic point of view. This is a typology related to all types of communicative acts. As a result of taking this approach, four main types of language homonymy were identified: sociolectal homonymy, discourse homonymy, ethnolinguistic homonymy and idiostylistic homonymy. The first three types were divided into more detailed categories, which resulted in dividing homonymy into: intrasociolectal and intersociolectal homonymy, intradiscourse and interdiscourse homonymy as well as intralanguage and interlanguage homonymy. Idiostylistic homonymy is an extraordinary type of homonymy and it is not divided in this way.
\end{abstract}

Martyna Król, Uniwersytet Jana Kochanowskiego w Kielcach, Kielce - Polska.

Zjawisko homonimii, rozumianej jako zbieżność formalna (w wymowie i/lub pisowni) jednostek leksykalnych przy jednoczesnej rozbieżności semantycznej, można poddać typologii z punktu widzenia dwóch kryteriów: funkcjonalnego i pragmatycznego. Pierwsze kryterium ma zastosowanie do podziału homonimów w oparciu o ich cechy strukturalne i relacje, jakie tworzą one w systemie językowym. W ten sposób zasadniczo można wyodrębnić trzy grupy: homonimy właściwe, homonimoidy i homoformy. Każdy z tych rodzajów jest wewnętrznie rozwarstwiony, jednak to nie ten podział znajduje się $\mathrm{w}$ centrum zainteresowania niniejszego opracowania. Podejście pragmatyczne porządkuje homonimy z punktu widzenia miejsca ich występowania $w$ ramach działalności językowej, a co za tym idzie - celu, jaki przyświeca konkretnemu aktowi wypowiedzi. Zgodnie z danym kryterium można wyróżnić trzy duże grupy: 1) homonimię socjolektalną, 2) homonimię dyskursywną i 3) homonimię etnojęzykową. Dane rodzaje homonimii dzielą się jeszcze z punktu widzenia tego, czy zjawisko zbieżności formalnej przy rozbieżności znaczeniowej zachodzi $\mathrm{w}$ granicach jednego socjolektu, dyskursu lub języka etnicznego, czy też na styku socjolektów, dyskursów lub języków. Zgodnie z tą zasadą można wyodrębnić homonimy wenątrzsocjolektalne i międzysocjolektalne oraz wewnątrzdys- 
kursywne i międzydyskursywne, a także homonimy intrajęzykowe i interjęzykowe.

Czwartą grupą homonimów wyróżnianą z pragmatycznego punktu widzenia jest homonimia idiostylistyczna. Dany typ homonimii odnosi się do przypadków indywidualnego pojmowania pewnych pojęć, co przekłada się na leksykalne znaczenie nominujących je jednostek językowych. Różnice znaczeń, które można zauważyć u poszczególnych użytkowników języka, są na tyle niewielkie, że pozwalają na komunikację na ogólnym poziomie, ale na tyle istotne, iż w komunikacji szczegółowej, specjalistycznej stają się podłożem nieporozumień, sprzeczek, a nawet poważnych konfliktów, sporów i kłótni. Z drugiej zaś strony umożliwiają manipulowanie opinią innych, mniej wyedukowanych terminologicznie, osób, co z kolei ma poważne konsekwencje społeczne i społeczno-kulturowe. Mowa tu choćby o takich problematycznych pojęciach, jak nacjonalizm, niebezpiecznie blisko graniczący z faszyzmem, życie, którego początek u człowieka wyznacza wyznanie czy ideologia, lub patriotyzm/patriota, do których odwołują się nacjonalistyczne bojówki, szczególnie aktywne w związku z polskim Świętem Niepodległości.

Jednymi z najbardziej aktualnych homonimów idiostylistycznych są słowa gender 'płeć społeczno-kulturowa' i genderyzm 'ideologia gender; uświadamianie dzieciom kwestii płci', których pojmowanie zdecydowanie odróżnia katolicką prawicę od liberalnej lewicy. Z ideologią gender otwarcie walczy polski Kościół, co najdobitniej uwidocznił list pasterski episkopatu, przygotowany na Dzień Rodziny, w którym biskupi napisali:

[1] Bardzo sprytnie pomija się fakt, że celem edukacji genderowej jest seksualizacja dzieci i młodzieży. Rozbudzanie seksualne już od najmłodszych lat prowadzi do uzależnień w sferze seksualnej, do zniewolenia człowieka. [...] W następstwie takiego wychowania, realizowanego przez młodzieżowych edukatorów seksualnych, młody człowiek staje się klientem koncernów farmaceutycznych, erotycznych, pornograficznych, pedofilskich i aborcyjnych (cyt. za „Polityka” 2014, nr 2).

Druga wersja listu została wprawdzie złagodzona, lecz niewiele to zmieniło $\mathrm{w}$ obrazie świata tych, którzy usłyszeli pierwszą wersję, czytaną we wszystkich polskich kościołach w czasie niedzielnej mszy. Nie zmieniła się także prawicowa publicystyka. W tygodniku „Uważam Rze” genderyzm został sprowadzony do nauki masturbacji i możliwości wyboru płci przez dziecko:

[2] Chcesz, aby twoje dziecko już w przedszkolu uczyło się masturbacji, a w gimnazjum ponownie wybrało swoją płeć? (cyt. za ibidem).

Trudno dziwić się ekspedientkom, których rozmowę zasłyszałam:

[3] - Co oni z nami robią?! Masakra!

- No, straszne! 
- Ale o co w ogóle chodzi z tym genderyzmem.

- No na przykład, dziecko, które rodzi się jako chłopiec czy dziewczynka, może sobie wybrać, czy chce być chłopcem czy dziewczynką.

Dalszej części rozmowy nie słyszałam, ale już ten fragment wystarczył, żeby uzmysłowić sobie, że $\mathrm{w}$ przypadku terminu gender należy mówić o istnieniu $\mathrm{w}$ języku polskim przynajmniej jednej pary homonimów: jeden $\mathrm{z}$ wyrazów odnajdziemy $\mathrm{w}$ idiolektach przedstawicieli katolickiej prawicy, a drugi - liberalnej lewicy. Poza tym istnieje ogromna ilość indywidualnych, idiostylistycznych homonimów o formie wyjściowej gender. Pojmowanie genderu determinowane jest przede wszystkim przez wyznawaną ideologią, ale zależy również od ogólnego poziomu intelektualnego poszczególnych użytkowników języka.

Dla ilustracji homonimii socjolektalnej przytoczę przykłady dwóch najczęściej używanych na internetowych portalach młodzieżowych (głównie na społecznościowym portalu Facebook) oraz na komunikatorach (typu GaduGadu, Skype czy Tlen) wyrazów melanż i żal. Jeden z nich tworzy relacje homonimiczne ze słowem należącym do tego samego socjolektu (slangu młodzieżowego), jak i z wyrazem odnoszącym się do innej społecznej odmiany języka, drugi zaś posiada homonimy wyłącznie w innych socjolektach.

Dla zdefiniowania słów należących do slangu młodzieżowego posiłkuję się społecznościowym słownikiem slangu i mowy potocznej o nazwie Miejski, który rejestruje najnowszą leksykę tego niezwykle dynamicznego socjolektu. Dzięki formie on-line słownik ten jest nie tylko łatwo dostępny dla użytkowników Internetu, ale także wrażliwy na zachodzące zmiany, gdyż po zalogowaniu na stronie słownika każdy może nanieść poprawki, uściślić czy dopełnić definicję. Ma to oczywiście swoje dobre i złe strony, gdyż niejednokrotnie pojawiają się definicje, które są wyłącznie efektem indywidualnego spojrzenia na pewne zagadnienie i które należałoby raczej określić jako przejaw homonimii idiostylistycznej. W związku z szybkością zmian $\mathrm{w}$ tym socjolekcie należy zaznaczyć, że opisane $\mathrm{w}$ danym artykule hasła zostały pobrane w listopadzie 2013 roku.

W wymienionym słowniku znajdują się dwa wyrazy żal. Zwolennicy teorii polisemii powiedzą zaś, że opisane są dwa znaczenia wyrazu żal, tym bardziej że twórcy słownika nie dbają o zachowanie różnicy między homonimią a polisemią. W związku z tym $\mathrm{w}$ rezultacie wyszukiwania na jednej stronie pod kolejnymi numerami ukazują się wszystkie wyrazy, których forma wyjściowa jest zbieżna, bez zaznaczania relacji etymologicznych, które uznawane są w lingwistyce za wyznacznik rozróżnienia między polisemią a homonimią. Definicja pierwszego z wyrazów - żal $1^{1}$ - jest bardzo

\footnotetext{
${ }^{1}$ Numeracja homonimów wynika z potrzeb niniejszego artykułu, nie ma zaś nic wspólnego z porządkiem derywacyjnym, który jest diametralnie odmienny, a którego przestrzeganie jest niezbędne w przypadku analizy słowotwórczej.
} 
szeroka, gdyż odnosi się do bardzo różnych stanów emocjonalnych (od smutku, przez zakłopotanie i zażenowanie, na zdziwieniu kończąc) [4], [5]. Wymawiany jest ten wyraz (i często odzwierciedla się to na piśmie) z wydłużoną samogłoską lub spółgłoską [1], a zatem żaaaal lub żallll. Używanie tego słowa jest charakterystyczne dla nastolatków (głównie gimnazjalistów), udzielających się bardzo aktywnie na komunikatorach oraz na forach internetowych i dodających tam swoje komentarze, drażniących innych użytkowników stosowaniem udziwnionej czcionki z nadużywaniem klawisza Caps Lock (np. rOOOoShoFy zamiast różowy). Osoby tego pokroju nazywane są pokemonami, trollami lub dziećmi neostrady.

[4] - Siemasz. Tam robisz?

- Żaaaaaaaal...

[5] - Co tam w szkole?

- Żallll...

Drugie słowo - żal 2 - jest wyrazem określanym jako kategoria stanu i oznacza odczucie w związku z wyjątkowo żenującą sytuacją [6].

[6] - Ej, no weź obczaj, koleś idzie sobie, a ja mówię „żal”, bo akurat miał takie żalowe spodnie, że żal.

Z tego słowa nastąpiło przeniesienie nazwy na styczne pojęcie człowieka - żal 3, który zachował się w sposób żenująco śmieszny lub też ubrał się nieodpowiednio do sytuacji, wieku, płci czy przynależności społecznej [7]. Jest to rodzaj obraźliwego określenia lub wyzwiska:

[7] - Zobacz, jakie spodnie ma ten koleś, ale z niego żal.

$\mathrm{W}$ ten sposób $\mathrm{w}$ wyniku transformacji słowotwórczej nastąpiło przeniesienie nazwy z pojęcia stanu na pojęcie człowieka, który taki stan wywołał. Muszę jednak nadmienić, że tego słowa nie było w przywoływanym słowniku, a odnalazłam je w innych internetowych źródłach.

Do języka literackiego należą dwa homonimy o formie wyjściowej żal: żal 4 'uczucie smutku z powodu utraty kogoś, czegoś, z powodu doznanego zawodu, czyjegoś cierpienia itp.' [8] i żal 5 'skrucha po popełnieniu czegoś złego' [9]. W standardzie językowym zaś występuje słowo żal 6 'pretensja do kogoś lub czegoś spowodowana przeżytym rozczarowaniem; rozgoryczenie' [10] (definicje podaję za USJP).

[8] Żalu, który czuła po stracie córki, nic nie mogło ukoić.

[9] Wyraził żal z powodu zaistniałej sytuacji.

[10] Mam do ciebie ogromny żal o to, że znowu nie umiałeś odmówić kolegom.

W ten oto sposób udało się wyodrębnić sześć homonimów socjolektalnych o formie wyjściowej żal. Trzy pierwsze homonimy należące do slangu młodzieżowego oraz parę homonimów żal 4 i żal 5 należy określić jako ho- 
monimy wewnątrzsocjolektalne, natomiast wobec siebie wzajemnie i w odniesieniu do ostatniego homonimu żal 6 stanowią one relację międzysocjolektalną.

Homonimia socjolektalna najczęściej idzie $\mathrm{w}$ parze $\mathrm{z}$ homonimią dyskursywną, gdyż dyferencjacja dotycząca przynależności do odmiany społecznej języka zwykle pokrywa się z rozróżnieniem homonimów jako obsługujących odmienne rodzaje dyskursów. Zatem pierwsze trzy homonimy żal występują w dyskursie potocznym, kolejne dwa - w dyskursie publicznym (wyraz żal 5 najbardziej charakterystyczny jest dla dyskursu religijnego: żal za grzechy i profesjonalno-administracyjnego - przykład [9]). Szósty homonim zasadniczo funkcjonuje $\mathrm{w}$ dyskursie potocznym, ale można go spotkać również w dyskursie publicznym. W taki oto sposób powstają relacje wewnątrzdyskursywne między trzema pierwszymi homonimami i elementami pary żal 4 - żal 5. Ostatni z homonimów tworzy z trzema pierwszymi homonimami stosunek homonimii wewnątrzdyskursywnej, zaś z wyrazami żal 4 i żal 5 - międzydyskursywnej.

Wyraz melanż 1 'impreza z dużą ilością różnego alkoholu i innych używek, w której bierze udział podobna ilość przedstawicieli obu płci' należy do slangu młodzieżowego i stosowany jest w dyskursie potocznym [11].

[11] Ale melanż był wczoraj! Stary, żałuj, że cię nie było: super stuff, wódka lała się strumieniami, a jakie laski...!

Słowo to powstało najprawdopodobniej w wyniku transformacji słowotwórczej. Jest to taki sposób tworzenia nowych jednostek leksykalnych, który polega na wykorzystaniu formalnej „powłoki” istniejącego w określonym języku wyrazu dla nazwania pojęcia stycznego lub podobnego do pojęcia, z którego „pobierana” jest forma. W tym konkretnym przypadku doszło do zapożyczenia nazwy z pojęcia podobnego, bowiem wyraz melanż 2, należący do języka literackiego i spotykany w dyskursie publicystycznym [12] czy naukowym [13], [14], oznacza 'pomieszanie różnych rzeczy, gatunków, stylów; mieszaninę'.

[12] Można tam było odnaleźć melanż wszelkich ras, swoisty tygiel etniczny.

[13] Gatunek tego utworu to melanż chronologicznie i teoretycznie różnych odmian literackich.

[14] Myślę, że nie można przyporządkować tego kościoła do jednego określonego stylu w architekturze. To jakiś przedziwny melanż stylów: trochę baroku, trochę gotyku, a reszta to jakaś orientalistyka.

W ten sam sposób - w wyniku transformacji słowotwórczej - powstał również wyraz melanż 3 'połączenie nitek o różnych barwach $\mathrm{w}$ tkaninie lub włóczce' [15], a stąd nazwa ta została metonimicznie przeniesiona na styczne pojęcie samej tkaniny czy włóczki z takich nitek (melanż 4) [16], a także koloru takiej tkaniny lub włóczki (melanż 5) [17]. 
[15] Tu został użyty trójkolorowy melanż.

[16] Te sukienki zrobione są z modnych melanżów.

[17] Czy oprócz czarnej i niebieskiej jest też tunika w melanżu?

Homonimy o formie wyjściowej melanż tworzą zatem równie ciekawą mozaikę socjolektalno-dyskursywną. Homonim oznaczony cyfrą 1 tworzy relację międzysocjolektalną i międzydyskursywną z pozostałymi homonimami. Drugi homonim jako jednostka leksykalna języka literackiego wchodzi w związek międzysocjolektalny z homonimami melanż 4 i melanż 5 jako należącymi do standardu językowego. Jednocześnie buduje on relację wewnątrzsocjolektalną z homonimem melanż 3, który, będąc profesjonalizmem, należy do języka literackiego. Jeśli chodzi o homonimię dyskursywną, to homonim melanż 2 tworzy relacje międzydyskursywne zarówno $\mathrm{z}$ homonimem melanż 3 (występującym $\mathrm{w}$ dyskursie profesjonalnym), jak i z pozostałymi dwoma homonimami, które funkcjonują bądź to w dyskursie profesjonalnym, bądź też potocznym (zwłaszcza melanż 5).

Homonimia etnojęzykowa różni się od innych pragmatycznie wyodrębnianych rodzajów homonimii tym, że dane zjawisko jest relewantne tylko w przypadku bilingwizmu, czyli znajomości dwóch języków (oczywiście możliwa jest także wielokrotność języków, którymi posługuje się dana osoba) i w sytuacji komunikacji międzykulturowej. Idiolekt niemal każdego użytkownika języka stanowi połączenie kilku (minimalnie dwóch) socjolektów, i prawie wszyscy prowadzimy naszą działalność językową, dostosowując ją do sytuacji, miejsca, celu i odbiorców, czyli uwzględniając typ dyskursu. Należy zauważyć wprawdzie, że humaniści mają większe problemy z rozróżnieniem dyskursu niż osoby z wykształceniem ścisłym. Fizyk, mówiąc w domu do małżonka "Włącz światło" czy "Zapal światło", zdecydowanie nie nominuje pojęcia naukowego "światło". Wynika to przede wszystkim z faktu, iż pojęcia, którymi w swojej działalności naukowej zajmują się przedstawiciele nauk ścisłych, można w większości sprowadzić do materialnych, empirycznie weryfikowalnych zjawisk, podczas gdy humaniści zajmują się wyłącznie abstrakcjami.

Natomiast mówienie o homonimii etnojęzykowej ma sens tylko w odniesieniu do tych, którzy $\mathrm{w}$ swojej działalności językowej przechodzą $\mathrm{z}$ jednego systemu językowego na inny. Osoby posługujące się wyłącznie jednym językiem etnicznym nie stykają się ze zjawiskiem homonimii etnojęzykowej, a co za tym idzie nie denotują tego fenomenu w swojej działalności językowej. Dlatego też o wyodrębnieniu homonimii intrajęzykowej można mówić jedynie wówczas, gdy zaistnieje homonimia interjęzykowa, ponieważ tylko $\mathrm{w}$ takim przypadku jest to metodologicznie uzasadnione.

Najczęściej istnienie homonimii intrajęzykowej uświadamiamy sobie wskutek zaistnienia nieporozumienia $\mathrm{w}$ komunikacji międzyjęzykowej. Nieprawidłowe użycie leksemu w takiej sytuacji zmusza do rewizji pojęć 
werbalizowanych przez zbieżne formalnie jednostki leksykalne języka ojczystego i obcego. Najpoważniejsze problemy dotyczą takich jednostek pierwszego języka, które odbierane są jako wieloznaczne. Przyczyna tkwi $\mathrm{w}$ tym, że następuje przenoszenie do systemu drugiego języka całej struktury znaczeń. Prawie zawsze jednak okazuje się, że takiej analogii zbudować nie można. Leksemom goracy 1 'mający wysoką temperaturę' [18] i gorący 2 'upalny, skwarny' [19] odpowiadają zupełnie inne wyrazy w języku rosyjskim - горячий [20] і жаркий [21].

[18] Uważaj na ten czajnik, bo jest bardzo goracy.

[19] Lato było gorace i suche.

[20] Горячий чай вас разогреет.

[21] В жаркий день следует много пить.

W ten sposób między leksemami gorący 2 - горячий tworzy się homonimia międzyjęzykowa. Takie zjawisko bardzo często świadczy o istnieniu homonimii wewnątrzjęzykowej. Tak właśnie jest w przypadku wyrazów goracy 1 - goracy 2.

Obserwacja i świadome rejestrowanie różnic w systemach semantycznych zestawianych języków zmusza do refleksji nad jednością pojęciową takich jednostek kognitywnych, które w językowym obrazie świata nominowane są za pośrednictwem leksemów o zbieżnej formie. Wobec faktu całkowitej rozbieżności formalnej ekwiwalentnych znaczeniowo jednostek leksykalnych $\mathrm{w}$ języku obcym dochodzi do uświadomienia sobie różnic między pojęciami nominowanymi przez zbieżne leksemy języka ojczystego. Różnice te są często ignorowane wskutek odniesienia pojęć do formalnie zbieżnych jednostek leksykalnych lub do jednej jednostki leksykalnej o kilku znaczeniach. Takie podejście sugeruje teoria polisemii, zgodnie z którą wyrazy mogą posiadać dwa lub więcej znaczeń. Praktyka kontaktów międzykulturowych świadczy na niekorzyść owej koncepcji, gdyż pozwala na uzmysłowienie sobie prymatu pojęcia nad formą znaku językowego. Fakt, iż w innym języku istnieją różne leksemy będące odpowiednikami, wydawałoby się, jednego słowa języka ojczystego, może świadczyć o istnieniu kilku pojęć o zbieżnych językowych „powłokach”. Jest zatem dowodem homonimii, nie zaś polisemii. Uzasadnienie tej tezy wymaga jednak wiele miejsca i obszerniejszej formy, dlatego znajdzie się ono w odrębnej monografii poświeconej zjawisku homonimii. 
